\title{
THE EFECT OF BIOMECHANICAL KNOWLEDGE, PHYSICAL CONDITION, AND LANDING TECHNIQUE ON ACL INJURY RISK OF SEPAK TAKRAW ATHLETES
}

\author{
Abdul Aziz Hakim,* Mulyana**, Sofyan Hanif*** \\ State University of Surabaya \\ State University of jakarta \\ State University of jakarta \\ Aahakim898@gmail.com \\ Mulyana.unj@unj.ac.id \\ Sofyanhanif.unj@unj.ac.id
}

\begin{abstract}
The purposes of this research are to obtain the effect of biomechanical knowledge, physical condition, and landing technique on ACL injury risk of sepak takraw athletes. This study was conducted at sepak takraw athletes of Jawa Timur Province. The numbers of 30 smasher athletes participated was chosen by total sampling technique. The data was collected has been analyzed by path analysis method test the hypothesis. The research finding are; (1) there is a direct effect of biomechanical knowledge on ACL injury risk, (2) there is a direct effect of physical condition on ACL injury risk, (3) there is a direct effect of landing technique on ACL injury risk, (4) there is a direct effect of biomechanical knowledge on landing technique, (5) there is a direct effect of physical condition on landing technique, (6) there is a non direct effect of biomechanical knowledge on ACL injury risk, (7) there is a non direct effect physical condition on ACL injury risk.
\end{abstract}

Keywords: biomechanical knowledge, physical condition, landing technique, and ACL injury risk

The development of takraw in East Java is none other than one of the results of the effort that has been done by the Management of PSTI East Java Province. Increasing matches between regions, may be one of the existing tricks (PSTI East Java, 2012). In addition, intensive training was also conducted on talented athletes in East Java through a regional training program (Puslatda). For successful PON 2012, sepak takraw puslatda in East Java has been done since 2009, this means for 3 years athletes. If there is an exercise program that continues, then there are usually side effects that often occur. This injury can be experienced by athletes with various causes. For example, improper techniques, physical inappropriateness, and so forth. In the research that has been done by Judge, in 2012 conducted on athletes Puslatda Sepak takraw East Java for PON 2012. Found all players son (100\%) had injured on 
the knee. While in other parts, 50\% hamstring, $43 \%$ angkel, and $21 \%$ in quadratus lumborum. While at the women's players $50 \%$ had a knee injury, $43 \%$ on the ankle, $28 \%$ on the hamstring and $21 \%$ on the lumborum quadrate (Hakim, 2013). And some athletes who plotted as spikers were diagnosed with Anterior Cruciate Ligament (ACL) . But in this study could not explain what is the cause of moderate-to-injury athletes.

In previous studies, anterior cruciate ligament injury (ACL) may be caused by overuse and movement patterns of Huston et al. (2000: 50-63). Inadequate mechanical engineering, lack of leg strength, and lack of leg flexibility are also factors that may affect savio, et al, (2006), Laow and Grimmer (2006). The motion of abduction of the knee also increases the risk of injury, ACL Hewett et al. (2006). Meanwhile, technical techniques used in the game sepak takraw tend to be related to factors that cause ACL injury above. Jumping with a ball-kick in the air, then landing, is a complex skill that resembles acrobatic movement, Hishasi, (2011). This movement is used in smash technique, Zahari, (2010). Smash in sepak takraw, especially rolling smash is a technic jump with one foot pedestal and landing with legs that are also used as the initial pedestal and punt when in the air, Judge, (2007: 99). Smesh movement is playing foot that used kepak ball into the opponent field. This technique is considered as very powerful to turn off the opposing game in the hope of making a point or number for the attack team, Hanif, (2016: 18). This trust serves as a basis for the coach to emphasize for all teams to do a steady smash smash, thus the number of games in game can be obtained, Darwis, Ratinus and Basa (1992: 83). However, this is also not just a belief, because after doing research in 2007 it was known that smesh became the most widely used technique to turn off the opposing game, either to attack or to survive, Judge, (2007). The implication in the training program is that the portion of the repetition of the smash technique will become ove rwhelming. The length of training and repetition is the result of the overuse and overtraining resulting in improper techniques used during smash, especially landing that is directly related to ACL injury.

Evaluation of the technique should continue to be undertaken in order to prevent the occurrence of sports injuries. Biomechanical analysis is one way to find out the errors of the movement of sports techniques, Knudson and Morisson, (2002: 56). Associated with injury, video analysis is also a more reliable way of knowing the mechanism of injury than the interview method, Krosshaug and Bahr, (2015). The results of this analysis can be the basis in the development of exercise programs in order to reduce ACL injury levels, as well as to identify the risk of ACL injury to athletes, Swart, et al (2014). However, in the case of sepak takraw sport, similar events still need to be investigated further so that, by knowing the cause of the injury, we can make efforts to prevent knee injury in athletes takraw. 
Furthermore, both limb and good limb conditions are also controlled by the central nervous system or Brain, Guyton and Hall (1996: 17). Control of motion by the brain is influenced by various things, including the perception formed by the information obtained by various senses that exist, Magill, (1980: 116). The information obtained through various sources in various ways is stored in the brain and known by knowledge, kebung, (2011: 75). Such knowledge will underlie the command of motion exercised by the brain to the muscles and bones. Knowledge stored in the brain forms the perception of motion. So the ability of human motion is also influenced by knowledge of motion. More and more, the more complex the knowledge will affect the decision-making of the nervous system in performing its every move, Clancy, (2006: 3). The decision-making process is part of the information processing which then generates motion commands to the muscles and skeletons. Thus motion errors are likely as a result of the lack of information obtained by the brain to control the movement itself, Drowatzky, (1981: 87). The more knowledge stored in the brain, the more choice of data to be processed into motion commands, Kiram, (1991: 210), Sugianto (1992: 75).

Fatigue became one of the causes of sports injuries. Because of the physical endurance or athlete's physical condition must support the needs of every sport, Hare, (1982: 145). If not, then fatigue that occurs due to poor physical condition, will increase the lactic acid in the blood. The high levels of lactic acid in the blood will inhibit the coordination function, Tangkudung, (2006) Russel, et al. (1984: 163). Thus if athletes experience fatigue will experience impaired coordination function. Meanwhile, in sepak takraw, many techniques require coordination. This condition will encourage athletes to go wrong technical movements that lead to increased risk of injury. The landing of smash is one of the most complex techniques requiring various biomotor components such as coordination, strength, flexibility, and balance to maintain body position when landing in safe condition from injury, Louw and Grimmer, (2006).

A less precise mechanical landing technique increases the risk of injury to the lower extremities, especially the knee. As the preceding description that the imperfections of this technique are most likely to be influenced by the knowledge related to the mechanics of motion, and the physical condition of each athlete. Assuming if both are good, then the landing technique will also be good. The result will reduce the risk of injury to the knee, ACL injury.

\section{Problem Formulation}

1. Is there a direct influence of movement mechanical knowledge on the risk of ACL injury?

2. Is there a direct effect of the level of physical condition on ACL recycling?

3. Is there a direct landing effect on the risk of ACL injury? 
4. Is there a direct influence of the mechanical knowledge of movement on the landing technique?

5. Is there a direct influence of the physical condition on the landing technique?

6. Is there an indirect effect of movement mechanical knowledge on ACL injury risk through landing technique?

7. Is there an indirect effect of physical condition on ACL injury risk through landing technique?

\section{METHOD}

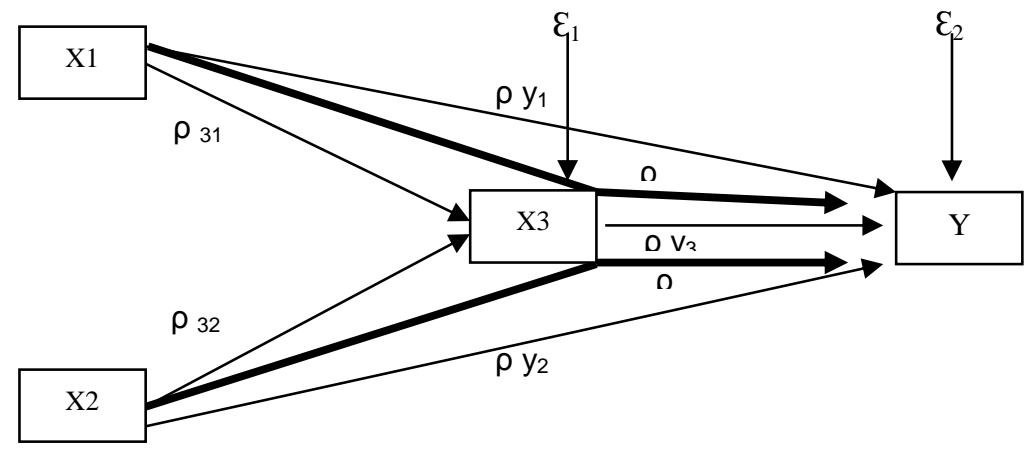

\section{Population and Sampling Techniques}

The population of this study is athletes sepak takraw who became the team of East Java. The sample frame is limited only to athletes plotting as speakers. Based on the data available in PSTI East Java province, athletes sepak takraw who became the team of East Java currently number 30 people. Sampling conducted in this research by using total sampling technique. Based on the category of athletes sepak takraw east java which is the speaker. Thus the entire sample consisted of 30 people

\section{Data collection technique}

Data obtained through: 1) The risk level of ACL injury (Y) was obtained by using Landing Error Scoring System (LESS) instrument, (Padua, 2011); 2) Qualitative biomechanical analysis is done by using slow motion (slow motion) recording assisted by check list list, Kinderbaoum, (2007: 120) compatibility of landing movement mechanics (X3); 3) a questionnaire device or questionnaire prepared in the form of five-point statement statements constructed on the basis of indicators, obtained after the theoretical study of mechanical knowledge variables of movement (X1); and 4) test seat and reach abilities, leg muscle strength composed by Johnson and Nelshon, (2000: 20), and as well as eye coordination for athlete takraw for physical condition level variables, (X2). 


\section{Data analysis technique}

Data analysis techniques used in this study are as follows: 1) Path analysis to see the influence of one variable against other variables in accordance with the established path, Suryanto, (1988: 167), Tangkudung (2016: 70). 2) Test requirements analysis that includes: (1) data normality test (2) test homogeneity of data; and (3) regression test. 3) Correlation statistics to see the relationships that occur between exogenous variables and endogenous variables that are related to each other.

\section{RESULT AND DISCUSSION}

Based on the results of data analysis and hypothesis test above, the following will be discussed explanation for each of the conclusions obtained.

\section{Direct Effect of Mechanized Knowledge of Movement on ACL Injury Risk}

The result of the hypothesis test above the path coefficient of mechanical influence of motion (X1) on the variable risk of ACL injury (Y) is pyx1 $=0.299$ and means. The magnitude of the direct influence of mechanical motion (X1) which directly affects the risk of ACL (Y) injury is $0.2992 \times 100 \%=8.940$. In other words that the mechanics of motion (X1) directly affect the variable risk of ACL (Y) injury by $8.940 \%$

based on the above findings can be explained that the concept is the knowledge stored in the brain. The knowledge is also as information stored in the memory of the brain, so that when needed in deciphering certain motion commands, the memory is reopened to the process to produce motion commands to the Magill skeletal muscles (1980: 233). The amount of variety and quality of the concept that a person has is very mempengaruinya in taking decisions motion. The concepts in memory are also closely related to the movement response that occurs, Williams, et al., (1999: 128).

Thus the better the quality and variety of knowledge or the concept of motion someone will the better the action of motion that he did. The mechanical knowledge or concept of motion mechanics will also be closely related to the mechanics of the movements performed. The words "if, when, or, and, so, then" become one example of the application of concept concepts to decision-making motion sports techniques, McPerson, (1999).

The results of the study above, supported by the theory of the use of knowledge of sports performance funds that have been developed by previous experts. Among the several theories, the most famous and also in accordance with the results of the above research is the theory of Active Control of Thought (ACT *) model developed by Anderson (1982). This theory states that the quality of knowledge will affect the quality of one's sports motion. This ACT * model system distinguishes memory into three namely declarative, production and working. 
Memory of declaratice consists of "what to do" information. While the memory production consists of information "how to do". The working memory consists of the latest information the system has accessed from the two memories above. Such information is obtained from long-term and temporary memory, as the main ingredient in making a motion decision. The process of decision-making of this movement, ranging from knowledge deklatarif, to procedural, until the compilation of knowledge to make action movement of this sport technique, allows the occurrence of errors. For that, training is still needed in an effort to reduce these mistakes. Due to faulty motion, is one of the main factors in the occurrence of ACL injury. The better the movement is, the lower the risk of injury.

\section{The Direct influence of the level of physical condition on the risk of ACL injury}

From the calculation result obtained path coefficient value of pyx $2=0.301$ so that path effect coefficient of physical condition (X2) to variable risk of ACL (Y) injury is mean. The magnitude of the contribution of direct effect of physical condition (X2) which directly affects the risk of ACL injury (Y) is $0.3012 \times 100 \%$ $=9.060$. In other words, the physical condition (X2) directly affects the variable risk of ACL (Y) injury by $9.060 \%$.

The contribution of this physical condition is supported by the results of research conducted by Zachary J. Domire, Dmitry Okorokov \& Katie Hughes. In this study mentioned that ACL injury occurs when landing with a straight leg (extension). Therefore, bending the knee (flexion) at the beginning of the landing contact, will be able to reduce the risk of ACL injury. The purpose of this research is to know the relationship between knee extensor strength and knee flexion angle during landing. 21 participants were asked to landing from a height of $65 \mathrm{~cm}$. at the same time also recorded using 3D kinematic analysis. In addition, also measured the maximum strength of his legs. This research resulted in a significant correlation between leg muscle strength (knee exetensor) to knee angle during landing. Although the findings do not show a direct causal relationship, but logically, it can be said that the weakness of the knee extensor muscle causes the landing to tend to be straight, thus increasing the risk of ACL injury. In general, physical weakness, resulting in weak muscle carrying capacity in absorbing the burden caused by movement. This, will encourage the greater the risk of injury. Conversely, if the physical well, then the risk of injury will be smaller.

Thus, the finding of a direct influence of physical conditions on ACL injury risk is supported by other theories and research results.

\section{Direct Effect of Landing Techniques on ACL Injury Risk}

From the hasilanalysis, the path coefficient value is pyx $3=0.642$. Thus the path coefficient of landing technique effect (X3) on the variable risk of ACL (Y) injury is significant. The magnitude of the direct effect contribution of landing 
technique (X3) which directly affects the risk of ACL (Y) injury is $0.6422 \times 100 \%$ $=41.216$

The landing of a leap is one of the sports techniques that often result in injury to the lower extremities, Louw, et al. (2003). Landing with poor technique also makes the risk of knee injury worse due to tissue and tendon damage. In Sports sepaktakraw, landing technique is the final part of the smash technique. This technique requires special skills, since not everyone can apply the landing technique. Called special skills, because it is not easy to do, it takes quite a long time, as well as the talent dipilikinnya.

From a number of reported studies, strong suspicion of knee injury in athlete sepak takraw caused by the use of the technique is not proportional, Nerphong, et al., (2000). This means that the mastery of the technique has not been mastered perfectly.

Thus the finding that landing technique had an effect on the risk of ACL injury was supported by previous theories and research results.

\section{Direct Influence Knowledge Mechanics Movement on Landing Technique}

From result of analysis of data above, obtained by path coefficient value equal to $\mathrm{p} \times 3 \times 1=0,891$ thus, coefficient of path of mechanical effect of motion (X1) to mechanical knowledge of motion (X3) is mean. The magnitude of the contribution of the direct influence of mechanical knowledge of motion (X1) which directly affects the technique of landing (X3) is $0.8912 \times 100 \%=79.388$

Knowledge is a collection of information information that becomes the basis of the brain in making motion commands. Motion mechanical knowledge is a collection of information about basic mechanical principle principles applied in sports movement. In information processing theory developed by Smith, said that the more variety of information or memory stored in the brain, the possibility of movement will be better, Drowatzky (1981). Psychologists also argue that the amount of information in this memory, if used correctly, will be very useful in cognitive processes to determine movement decisions or movement problems.

\section{Direct Effect of Physical Condition Level on Landing Technique}

From result of calculation obtained by path coefficient value equal to $p$ $\mathrm{x} 3 \mathrm{x} 2=0,401$ with path coefficient influence of physical condition (X2) to variable of landing technique (X3) is mean. The magnitude of the contribution of the direct effect of physical condition (X2) which directly affects the landing technique (X3) is $0.4012 \times 100 \%=16.080$

With regard to sepak takraw the physical condition of an athlete is one of the main supporters to realize to get the best performance. The physical condition of an athlete will affect the techniques used in sepak takraw sport. The better the 
physical condition of the athlete will facilitate it in the mastery of motion sports techniques, Hanfords, et al. (2016).

Like other techniques of sepak takraw, the landing technique is one of the techniques that requires good physical ability. In its implementation, the landing technique is dominated by explosive movements, coordination skills, and a balance of qualities. This is because the landing technique is a continuation of the smash technique. Or in other words the movement in the smash technique, always ends with a landing technique. Please note that when performing landing techniques, the main role in physical conditions, including balance, coordination, and leg muscle strength that serves as a foundation during the landing process. It seems from the description above the ability of physical condition is integrated with the technique of landing on sepak takraw sport. Therefore, a takraw athlete needs to be equipped with good engineering skills and physical condition. Physical and technical conditions are a must for athlete sepak takraw in ripening the capabilities that have and will have in order to achieve achievement in the future.

\section{Indirect Influence of Motion Mechanics Knowledge of ACL Injury Risk Through Landing Technique}

From the calculation results obtained value indirect influence of mechanical motion to ACL injury risk through landing technique is 0.572 . It may therefore be concluded that motor mechanics indirectly influence the risk of ACL injury through landing techniques.

Knowledge as a collection of information will affect the brain's decisionmaking to make a motion command on the skeletal muscles. Therefore, the quality of movement is also influenced by the number and variety of information or knowledge stored in brain memory. Conversely, if knowledge is limited, it will degrade the quality of one's movements. This, in the least choice of choice of information or memory as the basis for decision-making. This deficiency will encourage an athlete to make a mistake. While motion errors, is one of the factors causing injury in sport, Motion errors have implications for mechanical motion errors.

Likewise with ACL injuries. The mechanical errors of motion of the lower extremities during exercise, became one of the main factors of injury. This is supported by various findings that have been published in various journals. The greater the mechanical fault of movement the greater the risk of someone suffering from ACL injury.

\section{Indirect Influence of Physical Condition on Risk of ACL Injury Through Landing Technique}

From the above calculation results obtained value of indirect effect of physical condition to ACL injury risk through landing technique is 0.257 . It is 
therefore possible to conclude that physical conditions indirectly affect the risk of ACL injury through landing techniques

The physical condition of an athlete is also one of the main factors affecting athletes' performance. Thus, the quality of sporting techniques that an athlete performs, is also influenced by his physical qualities. Various sports techniques, including landing techniques. If the physical quality of the athlete is good takraw, then the quality of the ground tends to be good. Conversely, bad conditions will tend to be bad as well as sports techniques or landing techniques.

As mentioned above, that technical strength is also one of the main factors of sports injuries, including ACL injury, it can be expected that physical conditions can also affect the risk of AC injury

Strengthening the togok and thigh muscles reduces the risk of ACL injury and the provision of neuormuscular exercise before athletes participate in sports during high school will minimize mechanical errors of the lower extremity movement leading to injury to knee joints, Myer, Gregory et al. (2014). Increased knee strength and stability can also reduce the risk of ACL injury. Likewise, awareness in proper mechanical control of motion can help reduce the risk of injury, Allysa, (2015).

\section{CONCLUSION}

Based on the results of hypothesis testing and discussion of research, can be drawn conclusion as follows:

1. There is a significant direct effect of mechanical knowledge of motion on the risk of ACL injury.

2. There is a significant direct influence of physical condition on the risk of ACL injury

3. There is a significant direct effect of motion landing techniques on the risk of ACL injury

4. There is a direct, significant influence of mechanical knowledge of motion on the landing technique.

5. There is a significant direct influence of knowledge of physical condition on landing technique.

6. There is significant indirect influence of mechanical knowledge of motion against ACL injury risk through landing technique.

7. There is a significant indirect effect of physical condition on the risk of ACL injury through landing technique.

\section{REFERENCES}

Alyssa, Gardner. (2015). Neuromuscular Strengthening Exercise Following ACL and Meniscal Repair in 15 Year Old Female Athlete With Generalized Knee Laxity: A Case Report. 2015. Portland: Departement of Physical Therapy, University of New England. 
Anderson, J. R. (1982). Acquisition of cognitive skill. Psychological Review, 89, Cambridge: Havard University Press.

Clancy, Mary Ellen. (2006). Active Bodies, Actives Brains: Building Thinking Skills through Physical Activity. Human Kinetic.

Darwis, Ratinus dan Basa. (1992). Olahraga Pilihan Sepaktakraw. Jakarta: Depdikbud.

Drowatzky, John N. (1981). Motor Learning: Principles and Practices(Minnesota: Burgess Publishing Co.

Guyton dan Hall. (1996). Buku Ajar Fisiologi Kedokteran. (Philadelphia: W.B Sanders Company.

Hakim, Abdul Aziz. (2013). Common Injuries in Sepak Takraw (KualaLumpur, Proceeding International sport science and student conference).

Hakim, Abdul Aziz. (2007). Analisis Keterampilan Sepaktakraw pada Pemain Pelajar di Jawa Timur. Surabaya:Laporan Penelitian LPM Unesa.

Hakim, Abdul Aziz. (2007). SepakTakraw. Surabaya: Unesa Press.

Hanforsd, C., Davids, K., Bennet, S. and Button, C. Skill Acquisition in Sport: Some appication of evolving practice ecology. Journal of Sport Science.

Hanif, Achmad Sofyan. (2016). Manajemen Penyelenggaraan Pertandingan Sepak Takraw (Jakarta: PT Raja Grafindo Persada.

Hare, Dietrich. (1982). Principles of Sports Training. Berlin: Sportverlag Berlin.

Hewett TE,Myer GD, Ford KR, Heidt RS Jr, Colosimo AJ, McLean SG, van den Bogert AJ, Paterno MV, Succop P. (2016). Biomechanical Measures of neuromuscular control and valgus loading of the knee predict anterior cruciate ligament injury risk in female athletes: a prospective study. (Am J Sports Med).

Hisashi, Nagahama. (2011). Scientific Analysis in Sepaktakraw. Article Published at $5^{\text {th }}$ International Sports Medicine and Sports Science Conference, September.

Huston, L.J., Greenfield, M.L.V.H., dan Wojtys, E.M. (2000). Anterior cruciate ligament injuries in female athletes. (Clinical Orthopedics and Related Research).

Johnson Barry L., and Nelson Jack K. (2000). Practical Measurements for Evaluation in Physical Education. New York: MacMillan.

Kebung, Conrad. (2011). Filsafat Ilmu Pengetahuan. Jakarta: Prestasi Pustaka.

Kinderbaum. (2007). Biomechanics Qualitative. Canada: Mc Graw Hill.

Kiram Phil. Yanuar. (1991). Belajar Motorik. Jakarta: Departemen.

Knudson, Duane V. and Morrsison, Craig S. (2002). Qualitative Analysis of Human Movement. Human Kinetics.

Krosshaug, T. dan Bahr, R.. A Model-Based Image Matching Technique for Three Dimensional Reconstruction of Human Motion from Uncelebrated Video Sequences. J. Biomechanics.

Loow, Q. dan Grimmer, K. (2006). Biomechanical factors associated with the risk of knee injury when landing from a jump. (SAJSM, 2006). Vol 16 No 1 
Louw Q, Grimmer K, dan Vaughan K. Knee. (2003). Injury Patterns Among Young South African Basketball Players. South African Journal of Sports Medicine.

Magill, Richard A. (1980). Motor Learning: Concept and Application. Iowa: Wm. C. Brown Company.

McPherson, S.L. (1999). Knowledge representation and decision making in sport. Amsterdam: Elsevier Science.

Myer, Gregory, D. dkk. (2014). A Predictive Model to Estimate Knee-Abduction Moment: Implications for Development of Clinically Applicable Patellofemoral Pain Screening Tool in Female Athletes. (Journal of Athletic Training).

Nerphong, Wattana Jalayondeja, Roongtiwa Vatchalathiti. ((2000). Injuries In Thai Male National Sepaktakraw Team: 13th Asian Games Tournament, 18 International Symposium on Biomechanics in Sports.

Padua, Darin A., dkk. (2011). Reliability of the Landing Error Scoring SystemReal Time, a Clinical Assessment Tool of Jump-Landing Biomechanics. Journal of Sport Rehabilitation.

Pate, Russell R, Mc Clenghan, Bruce, dan Rotella, Robert. (1984). Scientific Foundation of. Coaching. New York: Sounders College Publisher.

PSTI. (2012. Jawa Timur. Laporan Kegiatan tahun 2012. Surabaya.

Savio L. Woo, Steven D Abrramowitch, Robert Kilger and Rui Liang. ((2006). Biomechanics of Knee Ligaments: injury, healing, and repair. Journal of Biomechanics 39.

Sugianto. (1992). Belajar Gerak. Jakarta: Kementerian Pendidikan dan Kebudayaan.

Suryanto. (1988). Metoda Statistika Multivariat (Jakarta: PPLPTK, Ditjen Dikti.

Swart, Eric, dkk. (2014). Prevention and Screening Programs for Anterior Cruciate Ligament Injuries in Young Athletes, a Cost-Effectiveness Analysis. The Journal of Bone and Joint Surgery, Incorporated.

Tangkudung, James. (2006). Ilmu Faal (Fisiologi). Jakarta: Penerbit Cerdas Jaya.

Tangkudung, James. (2016). Macam-macam Metodologi Penelitian (Uraian dan Contohnya). Jakarta: Lensa Media Pustaka Indonesia.

Williams, A.M., , K. Davids \& Williams, J.G. (1999). Visual Perception and action in Sport. London: E\&F Spon.

Zahari, Taha. (2010). Estimation of Head Impact Power on Sepaktakraw Players using Photogrammetric Method. Malaka-APIEM. 